\title{
Uncommon cause of hypercalcaemia in metastatic breast carcinoma
}

\author{
Rohit Barnabas, ${ }^{1}$ Ashish Singh, ${ }^{2}$ Mazhuvanchary Jacob Paul, ${ }^{3}$ Thomas Vizhalil Paul $^{4}$
}

'Department of Endocrinology, Diabetes and Metabolism, Christian Medical College, Vellore, India

${ }^{2}$ Department of Medical Oncology, Christian Medical College, Vellore, India ${ }^{3}$ Department of Endocrine Surgery, Christian Medical College, Vellore, India ${ }^{4}$ Christian Medical College, Vellore, India

\section{Correspondence to}

Professor Thomas Vizhalil Paul, thomasvpaul@yahoo.com

Accepted 25 January 2018

\section{DESCRIPTION}

A 61-year-old female diagnosed to have carcinoma of the left side with disseminated skeletal metastases (figure 1) 5 years back presented with worsening bone pains and fatigability for the past 6 months. She was earlier treated with palliative radiotherapy to the spine and had been on oral letrozole; this was followed by a palliative mastectomy. In addition, she received parenteral bisphosphonates for metastases. Clinical examination was unremarkable. Blood biochemistry showed elevated calcium $12.8 \mathrm{mg} / \mathrm{dL}$ (N: 8.3-10.4) with an alkaline phosphatase of $61 \mathrm{U} / \mathrm{L}(\mathrm{N}: 40-125)$ and creatinine of $0.7 \mathrm{mg} / \mathrm{dL}$ (N: $0.6-1.2), 25 \mathrm{OH}$ vitamin $\mathrm{D}$ of $26 \mathrm{ng} / \mathrm{mL}(\mathrm{N}: 30-75 \mathrm{ng} / \mathrm{mL}$ ) and elevated parathyroid hormone (PTH) of $202 \mathrm{pg} /$ $\mathrm{mL}$ (N: 8-50). Thus, she had a PTH-dependent hypercalcaemia and vitamin D insufficiency. We performed a sestamibi scan (figure 2A) and ultrasound of the neck (figure $2 \mathrm{~B}$ ), which revealed a right superior parathyroid adenoma. The present case had clinical and pathological features of metastatic breast carcinoma and serum chemistry and imaging features diagnostic of primary hyperparathyroidism (pHPT). A final diagnosis of pHPT in metastatic breast carcinoma causing hypercalcaemia was made. She was planned for parathyroid adenoma excision. In the hands of

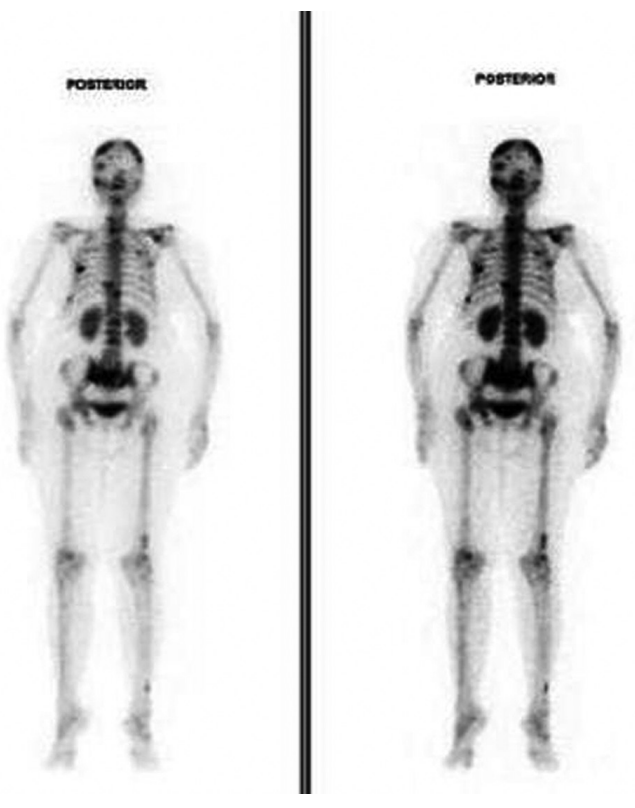

Figure 1 Bone scan had showed increased uptake in the skull, left humerus, multiple ribs, vertebrae, pelvic bones, bilateral femorii and tibiae.

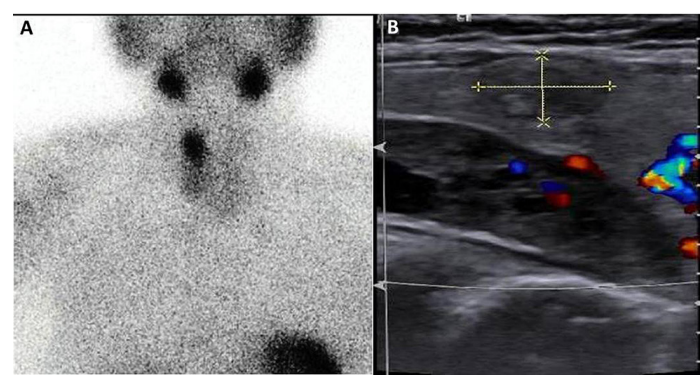

Figure 2 (A) The technetium sestamibi scan showed right superior parathyroid adenoma. (B) Ultrasound of the neck showed a concordant right superior parathyroid adenoma.

experienced parathyroid surgeon, minimally invasive parathyroid surgery (with excision of adenoma) carries negligible morbidity or surgical risk in the background of concordant functional and structural imaging localisation. Symptoms secondary to hypercalcaemia of pHPT (if hypercalcaemia is a predominantly contributed by parathyroid disease) will improve following excision of parathyroid adenoma and will have positive impact on quality of life. In addition, she was having stable metastatic disease over past few years and developed bone pains and fatigability recently.

In primary malignancy, hypercalcaemia is generally due to osteolytic metastasis or activity of circulating tumour-derived products. ${ }^{1}$ pHPT is known to be associated with increased prevalence of malignant tumours, especially breast carcinoma. Parathyroid adenoma has been seen in increased frequency in breast cancer compared with healthy controls. Breast carcinoma comprises one of the most frequent malignancies (standardised incidence ratio: 1.27) diagnosed after treatment of pHPT. ${ }^{2}$ The mechanisms of coexistence of pHPT

\section{Learning points}

- In solid tumour malignancy, hypercalcaemia is generally due to osteolytic metastasis or activity of circulating tumour-derived products.

- Although the occurrence is rare, it is prudent to evaluate for other treatable causes of hypercalcaemia such as pHPT in breast carcinoma and plan timely intervention to reduce morbidity associated with this coexistence. 
and malignancies are unknown. Both diseases can cause hypercalcaemia by independent mechanisms. ${ }^{3}$

Contributors RB wrote the manuscript. AS, MJP and TVP reviewed, revised and approved the manuscript.

Funding This research received no specific grant from any funding agency in the public, commercial or not-for-profit sectors.

Competing interests None declared.

Patient consent Obtained.

Provenance and peer review Not commissioned; externally peer reviewed. (c) BMJ Publishing Group Ltd (unless otherwise stated in the text of the article) 2018. All rights reserved. No commercial use is permitted unless otherwise expressly granted.

\section{REFERENCES}

1 Fierabracci P, Pinchera A, Miccoli P, et al. Increased prevalence of primary hyperparathyroidism in treated breast cancer. J Endocrinol Invest 2001;24:315-20.

2 Michels KB, Xue F, Brandt L, et al. Hyperparathyroidism and subsequent incidence of breast cancer. Int J Cancer 2004;110:449-51.

3 Norenstedt S, Granath F, Ekbom A, et al. Breast cancer associated with primary hyperparathyroidism: a nested case control study. Clin Epidemiol 2011;3:103-6.

Copyright 2018 BMJ Publishing Group. All rights reserved. For permission to reuse any of this content visit

http://group.bmj.com/group/rights-licensing/permissions.

BMJ Case Report Fellows may re-use this article for personal use and teaching without any further permission.

Become a Fellow of BMJ Case Reports today and you can:

- Submit as many cases as you like

Enjoy fast sympathetic peer review and rapid publication of accepted articles

Access all the published articles

Re-use any of the published material for personal use and teaching without further permission

For information on Institutional Fellowships contact consortiasales@bmjgroup.com

Visit casereports.bmj.com for more articles like this and to become a Fellow 